\title{
PENGARUH TEKNIK SEND A PROBLEM TERHADAP KEMAMPUAN MENULIS DAFTAR PUSTAKA SISWA KELAS XI SMA NEGERI 4 LUBUKLINGGAU
}

\author{
Noermanzah $^{1}$, Syaiful Abid ${ }^{2}$, Epa Aprika ${ }^{3}$ \\ Program Studi Pendidikan Bahasa dan Sastra Indonesia, STKIP PGRI Lubuklinggau ${ }^{1,2,3}$ \\ noermanzah@stkippgri-lubuklinggau.ac.id ${ }^{1}$
}

Submit, 26-04-2018 Accepted, 13-06-2018 Publish, 14-06-2018

\begin{abstract}
ABSTRAK
Penelitian ini bertujuan untuk mengetahui ada tidaknya pengaruh teknik send a problem terhadap kemampuan menulis daftar pustaka. Pengaruh tersebut ditunjukkan dari ketuntasan hasil kegiatan pembelajaran siswa di Kelas XI SMA Negeri 4 Lubuklinggau dalam menulis daftar pustaka setelah diterapkan teknik send a problem. Metode kuantitatif berupa eksperimen semu digunakan dalam menjawab tujuan penelitian ini. Teknik dalam pengumpulan data berupa teknik tes berbentuk uraian. Populasi penelitian yaitu seluruh siswa di kelas XI berjumlah 138 siswa yang terdiri dari 4 kelas. Sampel penelitian yaitu siswa di Kelas XI. MIA 4 yang berjumlah 34 siswa. Teknik analisis data dimulai dengan uji normalitas, dan dilanjutkan dengan uji t dengan melihat perbedaan antara nilai KKM yang dihopotesiskan sebesar 74 dengan nilai rata-rata postes. Berdasarkan hasil uji analisis dengan rumus uji t, to lebih besar daripada ttabel dengan tingkat signifikansi sebesar 5\% yaitu 2,60 lebih besar dari 2,04. Dengan demikian, hasil kegiatan pembelajaran siswa kelas XI SMA Negeri 4 Lubuklinggau dalam menulis daftar pustaka setelah diterapkan teknik send a problem secara signifikan tuntas.
\end{abstract}

Kata Kunci: Pengaruh, Teknik Send a Problem, Menulis Daftar Pustaka.

\begin{abstract}
The objective of this research was to determine whether there is influence of the send a problem technique to the ability to write a bibliography. Influence was shown from the completeness of the results of student learning class XI SMA Negeri 4 Lubuklinggau in writing a list of libraries after applied the send a problem technique. Quantitative methods of quasi-experiments are used in answering the purposes of this study. Techniques in collecting data in the form of a form of a description test technique. The research population was all students in class XI amounted to 138 students consisting of 4 classes. The sample in this research was class XI. MIA 4 which amounted to 34 students. Data analysis technique begins with the normality test, and continued with $t$ test by looking at the difference between the KKM value which was hypothesised is 74 with the mean postes. Based on the result of test analysis with t test formula, to greater than ttable at 5\% significance level that is 2.60 bigger than 2.04. Thus, the results of student learning class XI SMA Negeri 4 Lubuklinggau in writing the list of libraries after applied the send a problem technique significantly completed.
\end{abstract}

Keywords: Influence, Send a Problem Technique, Write Bibliography. 


\section{PENDAHULUAN}

Pengajaran bahasa Indonesia di beberapa sekolah memiliki peran, kedudukan, dan fungsi yang sangat penting sebagai sarana untuk melatih keterampilan siswa dalam menggunakan bahasa untuk kegiatan sehari-hari. Oleh karena itu, pengajaran Bahasa Indonesia bertujuan dalam meningkatkan kompetensi siswa dalam berkomunikasi dengan bahasa Indonesia, baik kemampuan lisan maupun kemampuan tertulis. Hal ini sesuai pendapat yang dijelaskan oleh Tarigan (2008), bahwa terampil berbahasa artinya terampil menyimak (listening skill), berbicara (speaking skill), membaca (reading skill), dan menulis (writing skill). Keempat keterampilan berbahasa itu mempunyai hubungan yang erat, saling berkaitan, dan juga memiliki pengaruh terhadap kemampuan siswa dalam memahami materi yang disampaikan guru.

Seorang guru hendaknya dapat memberikan kemudahan bagi siswa dalam menguasai materi tertentu sesuai dengan kurikulum. Guru mempunyai peranan penting dalam menciptakan pembelajaran yang inovatif, efektif, dan menyenangkan. Oleh karena itu, dalam kegiatan belajar mengajar seorang guru senantiasa berupaya untuk memilih teknik pembelajaran yang benar-benar efektif digunakan sehingga tujuan dari kegiatan pembelajaran yang diharapkan lebih mudah dicapai. Hal ini dijelaskan oleh Roestiyah (2001) yang menyatakan bahwa di dalam proses kegiatan pembelajaran, guru harus menggunakan teknik pembelajaran yang efektif dan menyenangkan, dengan tujuan para siswa dapat belajar secara aktif, kreatif, efisien dan tepat pada tujuan yang diharapkan.

Kemudian, diperjelas lagi oleh Wena (2010), bahwa pemilihan teknik pembelajaran yang tepat dibutuhkan dalam dalam setiap kegiatan pembelajaran. Hal ini bertujuan untuk mempermudah proses transfer ilmu kepada siswa dalam setiap tahapan pembelajaran yang direncanakan sehingga mampu mencapai tujuan pembelajaran dengan maksimal. Dengan demikian, tanpa teknik yang jelas, kegiatan pembelajaran tidak bisa terarah sesuai dengan tujuan pembelajaran yang sudah ditetapkan dan sangat sulit tercapai secara maksimal. Hal ini bermakna bahwa pembelajaran tidak mampu berjalan secara efektif, efisien, dan menyenangkan. Teknik pembelajaran yang kurang sesuai dengan materi atau kompetensi dasar yang diajarkan juga akan menimbulkan kesulitan bagi siswa dalam memahami konsep materi yang akan diberikan. 
Oleh sebab itu, para guru diharapkan dapat menerapkan teknik pembelajaran dengan baik kepada siswa. Salah satu pembelajaran yang dipelajari siswa di kelas XI SMA adalah menulis daftar pustaka. Menulis daftar pustaka merupakan kemampuan menulis sebuah daftar yang mencantumkan spesifikasi sebuah buku atau sumber rujukan yang meliputi: judul dari buku, nama penulis buku, kota terbit, penerbit buku, serta informasi lainnya yang berhubungan dengan aturan penulisan. Daftar pustaka biasanya diletakkan di halaman terakhir sebuah buku, disusun secara teratur, dan berurutan berdasarkan abjad (Atmaja, 2010). Sedangkan menurut Ilyas (2011), daftar pustaka merupakan daftar yang menuliskan beberapa judul sebuah buku, nama penulis, kota terbit, penerbit, dan lain-lain yang diletakkan pada posisi akhir suatu tulisan atau buku, yang penyusunannya berdasarkan urutan abjad.

Demikian juga menurut Keraf (dalam Ilyas, 2011) daftar pustaka dijelaskan sebagai daftar yang memuat judul beberapa buku, beberapa artikel, dan beberapa hal yang berhubungan dengan penerbitan yang memiliki hubungan dengan suatu tulisan atau sebagian dari tulisan atau karangan yang sedang dikerjakan. Selanjutnya menurut Haryanta (2007), daftar pustaka yaitu semacam rujukan seorang penulis dalam menyusun karyanya. Daftar pustaka juga bisa kita lihat di setiap makalah, skipsi, tesis, disertasi, laporan dari penelitian, maupun dalam esai. Sebuah daftar pustaka mempunyai peran yang penting dalam suatu karya tulis ilmiah, karena pada dasarnya karya tulis ilmiah yang tidak mencantumkan daftar pustaka sangat diragukan tingkat keilmiahannya atau masih bersifat karya fiksi. Dari beberapa pengertian daftar pustaka tersebut, penting bagi guru dalam memahami bagaimanakah cara memberikan pemahaman kepada siswa tentang keterampilan menulis daftar pustaka dengan baik dan benar.

Berdasarkan hasil observasi yang pernah dilakukan peneliti, diketahui bahwa kemampuan siswa di Kelas XI SMA Negeri 4 Lubuklinggau dalam menulis daftar pustaka belum mencapai tujuan pembelajaran yang ditargetkan. Hal ini dibuktikan dengan melihat nilai rata-rata ulangan harian di salah satu kelas yaitu Kelas XI SMAN 4 Lubuklinggau tentang menulis daftar pustaka yang diperoleh nilai rata-rata siswa baru sebesar 69,82 dari jumlah keseluruhan siswa 32 orang. Apabila dirinci diketahui 14 $(43,75 \%)$ siswa tuntas dan $18(56,25 \%)$ siswa yang belum tuntas. Hal ini disebabkan 
belum tepat dan maksimalnya teknik pembelajaran yang diterapkan guru di sekolah, sehingga siswa belum begitu memahami aturan penulisan daftar pustaka secara benar.

Salah satu upaya untuk menuntaskan permasalahan kemampuan siswa dalam menulis daftar pustaka ialah dengan menggunakan teknik pembelajaran yang tepat dalam penyampaian materi pembelajaran menulis daftar pustaka. Menurut Trianto (2012), teknik atau model pembelajaran merupakan kegiatan perencanaan yang disusun sebagai panduan dalam merencanakan langkah-langkah pembelajaran di kelas atau kegiatan pembelajaran dalam suatu tutorial. Sedangkan menurut Joice (dalam Trianto, 2012), teknik pembelajaran merupakan kegiatan perencanaan yang dapat digunakan untuk mendesain langkah-langkah pembelajaran sacara tatap muka atau tutorial di dalam kelas dan bertujuan dalam menetapkan perangkat pembelajaran seperti sumber belajar yang berasal dari beberapa buku, beberapa film, beberapa program media berbasis komputer, dan kurikulum. Teknik pembelajaran membantu guru dalam mengarahkan proses pembelajaran dan merancang pembelajaran yang mampu membantu siswa dalam mencapai tujuan pembelajaran.

Berdasarkan pendapat tersebut, maka dapat disimpulkan teknik pembelajaran sebagai langkah-langkah pembelajaran yang disusun dan diterapkan oleh guru dalam menyajikan materi pelajaran, agar terjadi proses pembelajaran untuk mencapai tujuan. Salah satu alternatif teknik pembelajaran yang bisa diterapkan di kelas untuk melibatkan peran serta siswa dalam proses belajar-mengajar adalah teknik send a problem. Teknik pembelajaran send a problem merupakan salah satu dari teknik pembelajaran cooperative lerning yang berbasis masalah. Teknik ini dilakukan dengan cara siswa dibentuk dalam kelompok secara heterogen atau dikelompokkan dengan tingkat kemampuan siswa yang merata dalam setiap kelompok, kemudian per kelompok diberikan masalah oleh guru dan dilanjutkan dengan memberikan solusi kepada siswa yang ada di sampingnya untuk ditindaklanjuti bagaimana solusi terbaik dari kelompok berikutnya.

Menurut Barkley (dalam Zakkie, 2012), teknik send a problem merupakan pembelajaran yang dilakukan dengan setiap kelompok mencoba menerima suatu masalah yang diberikan guru, lalu mencoba menyelesaikannya, kemudian mengirimkan masalah tersebut dan solusinya kepada kelompok yang berada di sampingnya. Tanpa melihat solusi kelompok sebelumnya, kelompok berikutnya ini sulit menyelesaikan 
masalah yang mereka terima. Setelah cukup banyak kelompok aktif berpartisipasi dalam proses menerima masalah dan sudah cukup siap untuk menjawab permasalahan, kelompok-kelompok ini kemudian menganalisis, mengevaluasi, dan mensintesiskan respons terhadap masalah yang mereka terima dan melaporkan solusi terbaiknya di hadapan kelas. Melalui teknik pembelajaran berbasis masalah send a problem ini, siswa diharapkan termotivasi untuk ikut aktif dalam proses pembelajaran yang berlangsung. Peneliti memilih teknik pembelajaran berbasis masalah send a problem ini karena peneliti ingin menerapkan teknik pembelajaran dengan langkah-langkah pembelajaran yang dapat meningkatkan keterlibatan siswa dalam mempelajari bahasa dan sastra Indonesia, sehingga dapat meningkatkan kemampuan siswa dalam mencapai tujuan pembelajaran.

Teknik send a problem menurut Kagan (1992), dapat diterapkan dalam pembelajaran, dengan langkah-langkah sebagai berikut: (1) Tempatkan siswa dalam kelompok kecil; (2) Minta setiap kelompok untuk memikirkan situasi terkait topik dan tulis ini pada kartu atau selembar kertas (bisa dari siswa atau dipilih oleh guru). Masalahnya melekat pada bagian luar folder dan bertukar dengan kelompok lain; (3) Berikan pada tiga kelompok hingga lima menit untuk mempertimbangkan masalah dan bertukar pikiran tentang berbagai solusi atau berikan tanggapan terhadap masalah. Solusi atau tanggapan tercantum dan diapit di dalam berkas/map; (4) Berkas ini kemudian diteruskan ke grup berikutnya dan proses diulang. Ingatkan kelompok untuk tidak melihat berkas atau membaca solusi atau tanggapan yang diidentifikasi oleh kelompok sebelumnya; (5) Ulangi proses ini sampai kelompok menyelesaikan beberapa masalah; dan (6) Kelompok harus diberikan masalah asli mereka untuk meninjau semua gagasan yang disarankan dan mengembangkan daftar solusi atau jawaban yang diprioritaskan. Daftar ini kemudian disajikan di depan kelas untuk didiskusikan dan memutuskan tanggapan mana yang benar-benar mereka percaya untuk digunakan.

Hasil penelitian relevan yang berkaitan dengan penerapan teknik send a problem yaitu penelitian yang dilaksanakan oleh Amilia dan Sisbiyanto (2016) menunjukkan bahwa dari hasil pre-test sebelum diberikan teknik send a problem, skor rata-rata dari kelompok eksperimen adalah 62,80 dan kelompok kontrol adalah 62,77. Setelah diberikan teknik send a problem, hasil postes dari kelompok eksperimen adalah 75,57 sedangkan kelompok kontrol adalah 68,57. Sampel independen t-test yang digunakan 
dalam penelitian ini menunjukkan bahwa ada perbedaan yang signifikan antara postes kelompok kontrol dan kelompok eksperimen. Dari hasil penelitian ini, khususnya dalam mengajar menulis teks analitis eksposisi menggunakan teknik send a problem adalah efektif daripada cara konvensional. Dalam penelitian ini, guru bahasa Inggris disarankan untuk memperhatikan dengan lebih baik dalam berbagai teknik mereka dalam mengajar menulis jenis teks apa saja terutama teks eksposisi.

Penelitian relevan juga dilakukan oleh Yuliane (2017) menunjukkan bahwa terdapat pengaruh yang signifikan teknik pembelajaran tipe kooperatif dengan teknik send a problem terhadap kemampuan dalam berpikir kritis matematis siswa di kelas VIII MTs Negeri 1 Bandar Lampung tahun ajaran 2016/2017. Berdasarkan beberapa hasil penelitian relevan tersebut, menunjukkan bahwa secara umum teknik send a problem mampu memberikan peningkatan hasil belajar siswa. Kemudian, teknik send $a$ problem juga belum digunakan dalam menuntaskan kemampuan menulis daftar pustaka. Untuk itu, penelitian ini bertujuan ingin membuktikan "Adakah pengaruh teknik send a problem dalam menuntaskan kemampuan menulis daftar pustaka siswa di Kelas XI SMA Negeri 4 Lubuklinggau? Dengan harapan, menjadi salah satu alternatif bagi guru dan dosen bahasa Indonesia dalam meningkatkan kemampuan berbahasa Indonesia siswa atau mahasiswa khususnya kemampuan dalam menulis daftar pustaka.

\section{METODE PENELITIAN}

Metode penelitian untuk pengambilan data dan menganalisis data penelitian digunakan metode eksperimen semu dengan uji beda satu sampel. Uji beda satu sampel yaitu pengujian yang digunakan untuk mengetahui apakah nilai yang ditetapkan sebagai acuan atau sebagai nilai pembanding berbeda ataukah sama dengan rata-rata sebuah sampel secara nyata (Rustam, 2016). Nilai yang dijadikan acuan yaitu nilai KKM bahasa Indonesia sebesar 74. Populasi penelitian yaitu semua siswa di Kelas XI SMA Negeri 4 Lubuklinggau sebanyak 138 orang yang terdiri dari 4 kelas. Secara umum anggota dari populasi cukup homogen dari kemampuan berbahasanya dan disesuaikan dengan metode uji beda satu sampel, maka ditetapkan 1 sampel penelitian yaitu satu kelas sebagai sampel penelitian, yaitu Kelas XI. MIA. 4 berjumlah 34 orang.

Teknik dalam pengumpulan data penelitian digunakan teknik tes dengan jenis tes uraian. Teknik analisis data dimulai dengan menghitung normalitas data, 
menghitung uji $\mathrm{t}$ atau $\mathrm{t}$ hitung, dan dilanjutkan dengan pengujian hipotesis. Apabila thitung > ttabel maka $\mathrm{H} 1$ diterima dan tolak Ho, maka terdapat pengaruh teknik send a problem dalam menuntaskan kemampuan menulis daftar pustaka siswa di Kelas XI SMA Negeri 4 Lubuklinggau atau ada peningkatan rata-rata nilai kemampuan menulis daftar pustaka siswa setelah diajar dengan teknik send a problem.

\section{HASIL PENELITIAN}

Dari hasil penerapan teknik pembelajaran berbasis masalah send a problem pada pembelajaran menulis daftar pustaka siswa di Kelas XI SMA Negeri 4 Lubuklinggau diperoleh hasil tes akhir yang mencapai nilai ketuntasan di atas nilai KKM 74 yaitu sebanyak 26 siswa atau sebesar 76, 47\%. Hasil tes akhir atau postes menulis daftar pustaka dapat ditunjukkan pada tabel 1 berikut.

Tabel 1.

Hasil Tes Akhir (Postes) Kemampuan Menulis Daftar Pustaka

\begin{tabular}{cccc}
\hline \multirow{2}{*}{ Nilai } & \multirow{2}{*}{ Keterangan } & \multicolumn{2}{c}{ Postes } \\
\cline { 3 - 4 } & & Frekuensi & Persentase \\
\hline$>74$ & Tuntas & 26 & $76,47 \%$ \\
\hline$<74$ & Tidak Tuntas & 8 & $23,53 \%$ \\
\hline \multicolumn{2}{c}{ Jumlah } & 34 Orang & $100 \%$ \\
\hline
\end{tabular}

Berdasarkan tabel 1 di atas, diperoleh informasi bahwa siswa yang memperoleh nilai > 74 dengan kriteria tuntas adalah 26 orang $(76,47 \%)$, sedangkan nilai $<74$ dengan kriteria tidak tuntas adalah 8 orang $(23,53 \%)$. Kemudian, hasil uji normalitas yang digunakan untuk mengetahui kenormalan data yaitu menggunakan rumus uji kecocokan $\mathrm{x}^{2}$ (chi kuadrat), dengan hasil data berdistribusi normal. Kemudian, dari hasil uji $\mathrm{t}$ atau $\mathrm{t}$ hitung diperoleh nilai $\mathrm{t}_{\mathrm{o}}$ sebesar 2,60. Hasil ini dikonsultasikan dengan tabel, dan pada tingkat signifikan 5\% sebesar 2,04. Hasil perhitungan ini yaitu 3,81>2,04. Berdasarkan penjelasan tersebut menunjukkan siswa di Kelas XI SMA Negeri 4 Lubuklinggau dalam menulis daftar setelah diterapkan teknik send a problem secara signifikan tuntas atau terdapat peningkatan.

\section{PEMBAHASAN}

Permasalahan yang dibahas dalam penelitian ini adalah apakah hasil belajar siswa kelas XI SMA Negeri 4 Lubuklinggau dalam menulis daftar pustaka setelah 
diterapkan teknik send a problem secara signifikan tuntas. Dalam penelitian ini tes yang digunakan berbentuk tes esai terhadap kemampuan menulis daftar pustaka. Pelaksanaan penelitian ini dilakukan dengan kegiatan treatmen atau pembelajaran menulis daftar pustaka dengan menggunakan teknik send a problem, dan diakhiri dengan kegiatan postes untuk mengetahui hasil kegiatan pembelajaran berupa kemampuan menulis daftar pustaka siswa setelah diterapkan teknik send a problem.

Sewaktu proses kegiatan pembelajaran dengan teknik send a problem, peneliti mengamati siswa dengan cara memperhatikan keaktifan siswa dalam menulis daftar pustaka masing-masing, ternyata setelah dilakukan pembelajaran dengan teknik send a problem siswa terlihat belajar lebih aktif, berusaha untuk bertanggung jawab, dan memiliki sikap mandiri. Sesuai dengan pendapat Barkley (dalam Zakkie, 2012), bahwa teknik send a problem merupakan pembelajaran pemecahan masalah, mencoba menyelesaikannya, kemudian mengirimkan masalah tersebut dan solusinya kepada kelompok yang berada di sampingnya. Dengan melihat solusi kelompok sebelumnya, kelompok berikutnya sangat terbantu sehingga aktif dan mampu menyelesaikan masalah yang mereka terima.

Setelah cukup banyak kelompok aktif berperanserta dan sudah cukup memahami masalah yang diberikan, kelompok-kelompok ini, kemudian menganalisis, mengevaluasi, dan menyintesiskan respons-respons terhadap masalah yang mereka terima dan melaporkan solusi terbaiknya di hadapan seluruh kelas. Langkah-langkah pembelajaran dalam teknik send a problem, terlihat keunggulan dari teknik pembelajaran ini yaitu siswa benar-benar dapat menguasai pengetahuannya tentang menulis daftar pustaka, meningkatkan semangat belajar siswa, membantu terciptanya suasana belajar yang kondusif, serta mendorong dan mengembangkan proses berpikir kreatif. Sedangkan ditemukan pula kekurangan teknik send a problem yaitu siswa yang kurang berperanserta dalam pembelajaran, mengalami kesulitan dalam menguasai materi pembelajaran. Untuk itu, dibutuhkan perhatian khusus pada siswa yang kurang aktif, misalnya dengan memberikan penghargaan berupa sanjungan dan motivasi khusus kepada siswa yang kurang aktif tersebut.

Berdasarkan hasil penelitian, diketahui hasil tes esai atau uraian dari kemampuan menulis daftar pustaka setelah menggunakan teknik send a problem diperoleh nilai rata- rata 77,38 dengan rincian siswa yang memperoleh nilai $>74$ 
dengan kriteria tuntas adalah 26 orang $(76,47 \%)$, sedangkan nilai $<74$ dengan kriteria tidak tuntas adalah 8 orang $(23,53 \%)$. Rincian nilai yang diperoleh siswa ini menunjukkan bahwa sebagian besar siswa mengalami peningkatan kemampuan dalam menulis daftar pustaka. Hal ini disebabkan dengan menggunakan teknik send a problem ternyata mampu memotivasi siswa untuk berkonsentrasi menulis daftar pustaka dengan aktif, karena mereka dapat saling mengirim masalah untuk diselesaikan tiap kelompok, sehingga hasil tes esai menulis daftar pustaka yang diberikan mampu dijawab oleh siswa dengan benar dan maksimal. Dalam hal ini, siswa membiasakan diri untuk menyelesaikan masalah membuat daftar pustaka dari berbagai jenis rujukan. Dengan pembiasaan tersebut menghasilkan budaya mutu yang kreatif dan inovatif dalam menguasai kemampuan menulis daftar pustaka.

Berdasarkan data nilai yang dicapai oleh siswa, dapat dijelaskan bahwa setelah mendapatkan pengajaran dengan menggunakan teknik send a problem, ternyata hasil tes esai kemampuan menulis daftar pustaka siswa meningkat. Berdasarkan hasil analisis rumus statistik yaitu uji " $t$ ", diketahui $t_{0}=2,60$. Jika hasil ini dikonsultasikan dengan $t_{\text {tabel }}$ dengan tingkat signifikansi 5\% diperoleh harga $t_{t} 2,04$. Hal ini menunjukan bahwa hasil perhitungan $t_{o}$ lebih besar dari pada $t_{t}$ baik pada tingkat signifikan $5 \%$. Dengan demikian, hipotesis menyatakan bahwa hasil kegiatan pembelajaran siswa di Kelas XI SMA Negeri 4 Lubuklinggau dalam menulis daftar pustaka setelah diterapkan teknik send a problem secara signifikan tuntas, terbukti kebenarannya.

Dengan ketuntasan belajar dalam menulis daftar pustaka ini dapat dijadikan dasar bagi guru bahwa teknik send a problem, apabila dilaksanakan sesuai langkah kerjanya, maka akan mampu memotivasi para siswa dalam belajar dan mampu mengusasi materi yang dipelajarinya melalui diskusi dalam kelompok. Langkah kerja yang dilakukan sudah sesuai dengan pendapat Barkley (dalam Zakkie, 2012) bahwa langkah-langkah teknik send a problem yaitu: 1) per kelompok diberikan sebuah masalah oleh guru; 2) siswa mencoba menyelesaikannya; 3) siswa mengirimkan masalah tersebut dan solusinya kepada kelompok berikutnya; 4) tanpa melihat solusi kelompok sebelumnya, kelompok berikutnya menyelesaikan masalah yang mereka terima; 5) setelah cukup banyak kelompok aktif berpartisipasi dan sudah cukup memahami permasalahan, kelompok-kelompok ini kemudian menganalisis, 
mengevaluasi, dan menyintesiskan respons-respons terhadap masalah yang mereka terima; dan 6) tiap kelompok melaporkan solusi terbaiknya di depan kelas.

Selain itu, teknik send a problem juga bukan hanya bisa digunakan dalam materi menulis daftar pustaka, tetapi bisa juga digunakan dalam materi atau kompetensi dasar lain yang sifatnya penguasaan suatu konsep yang lebih dalam. Seperti penelitian relevan yang dilaksanakan oleh Amilia dan Sisbiyanto (2016) menunjukkan bahwa teknik send a problem efektif meningkatkan kemampuan menulis teks analitis eksposisi siswa SMA Negeri 8 Semarang. Kemudian, penelitian yang dilakukan oleh Yuliane (2017) juga menunjukkan bahwa terdapat pengaruh yang signifikan teknik send a problem terhadap kemampuan dalam berpikir kritis matematis siswa di kelas VIII MTs Negeri 1 Bandar Lampung tahun ajaran 2016/2017. Hal ini menunjukkan bahwa teknik send a problem sebagai teknik dalam menyelesaikan masalah dalam beberapa kelompok kecil dan mempresentasikan solusi yang terbaik dalam kelas, benar-benar mampu membantu siswa dalam memahami suatu materi pelajaran dan membantu guru dalam mencapai tujuan pembelajaran.

\section{SIMPULAN}

Dari hasil penelitian dan pembahasan diperoleh kesimpulan bahwa ada pengaruh yang signifikan teknik send a problem terhadap kemampuan menulis daftar pustaka. Pengaruh tersebut ditunjukkan dari hasil ketuntasan hasil tes esai atau uraian yang diberikan pada akhir kegiatan pembelajaran siswa di Kelas XI SMA Negeri 4 Lubuklinggau dalam menulis daftar pustaka yaitu sebesar $76,47 \%$ setelah diterapkan teknik send a problem. Kemudian, berdasarkan hasil analisis statistik inferensial parametrik yaitu uji “ $\mathrm{t}$ ", diketahui $\mathrm{t}_{\mathrm{o}}=2,60$. Jika hasil ini dikonsultasikan dengan $\mathrm{t}_{\text {tabel }}$

pada tingkat signifikansi sebesar 5\% diperoleh harga $t_{t} 2,04$. Hal ini menunjukkan bahwa hasil perhitungan $t_{0}$ lebih besar dari pada $t_{t}$ baik pada taraf signifikan $5 \%$. Dengan demikian, hasil kegiatan belajar siswa Kelas XI SMA Negeri 4 Lubuklinggau dalam menulis daftar pustaka setelah diterapkan teknik send a problem secara signifikan tuntas. Adanya pengaruh teknik send a problem terhadap kemampuan menulis daftar pustaka karena siswa terbantu dengan kegiatan penyelesaian masalah, dengan cara diskusi bersama dalam kelompok tentang tugas menulis daftar pustaka dari berbagai sumber referensi. Kegiatan penyelesaian masalah dalam kelompok ini, menjadikan 
siswa terbiasa menyusun daftar pustaka sehingga ketika guru memberikan tugas secara individu, siswa sudah mampu menyelesaikan soal menulis daftar pustaka.

\section{DAFTAR PUSTAKA}

Amilia, I. K. \& Sisbiyanto, A. (2016). The effectiveness of send a problem technique for teaching writing an analytical exposition text: A quasi-experimental study of the eleventh grade students of SMA N 8 Semarang in the academic year 2015/2016. ELT Forum: Journal of English Language Teaching, Vol. 5(2). Universitas Negeri Semarang: Semarang.

Atmaja, J. F. (2010). Buku Lengkap Bahasa Indonesia \& Peribahasa. Yogyakarta: Pustaka Widyatama.

Haryanta. (2007). Panduan Belajar Bahasa dan Sastra Indonesia: Untuk SMA dan MA Kelas X). Jakarta: Esis, PT Gelora Aksara Pratama.

Ilyas, N. (2011). Inti Sari dan Soal Bahasa dan Sastra Indonesia SMA/MA. Jakarta: BA Printing.

Kagan, S. (1992). Cooperative Learning Resources for Teachers. San Capistrano, CA: Resources for Teachers, Inc.

Roestiyah, N.K. (2001). Strategi Belajar Mengajar. Jakarta: Rineka Cipta.

Rustam, A. (2016). Dasar-Dasar Statistik. Kolaka: Putri Yolanda.

Tarigan, H. G. (2008). Membaca sebagai Suatu Keterampilan Berbahasa. Bandung: Angkasa.

Trianto. (2012). Teknik Pembelajaran Terpadu. Jakarta: Bumi Aksara.

Wena. (2010). Teknik Pembelajaran Inovatif. Jakarta Timur: PT Bumi Aksara.

Yuliane, E. (2017). Pengaruh teknik pembelajaran kooperatif teknik send a problem dengan pendekatan analitik dan sintetik terhadap kemampuan berpikir kritis matematis peserta didik Kelas VIII MTS Negeri 1 Bandar Lampung tahun pelajaran 2016/2017. Undergraduate Thesis, UIN Raden Intan Lampung. Diakses pada 20 November 2017. http://repository.radenintan.ac.id/1644/

Zakkie. (2012). Collaborative Learning Techniques. Bandung: Nusa Media. 